\title{
Strategy and Policy for Strengthening the Agricultural Cooperative Business in East Java, Indonesia
}

\author{
Soetriono ${ }^{1 *}$, Djoko Soejono ${ }^{1}$, Dimas B. Zahrosa ${ }^{1}$, Ariq Dewi Maharani ${ }^{1}$, \\ and SRDM R Hanafie ${ }^{2}$ \\ ${ }^{1}$ Department of Agribusiness, Faculty of Agriculture, University of Jember \\ ${ }^{2}$ Department of Agribusiness, Faculty of Agriculture, Widyagama University of Malang
}

(Received December 5, 2018; Accepted March 10, 2019; Published April 18, 2019)

\begin{abstract}
The purpose of the study is to analyze business performance, financial resources, and strategies for developing agricultural cooperatives in East Java. The research approach used was a qualitative and quantitative descriptive approach. The research locations were in Malang regencies, Lumajang, Bojonegoro, Tulungagung, Madiun, Situbondo, Banyuwangi, and Sumenep. Secondary and primary data, including cooperative performance, SWOT, and financial data, were carried out to obtain a cooperative description. The analysis methods used were descriptive analysis, financial ratios, SWOT and FFA. The results showed that agricultural cooperatives showed a strong institutional position in supporting food sovereignty. The number of active cooperatives reached 27461 units with 7.62 million members. Cooperatives in healthy performance were found in Malang, Situbondo, Tulungagung and Madiun Regencies. The cooperative development should be emphasized on implementing functions of member annual meeting, developing innovation, making economic partnerships, strengthening capital formation, applying positive values of cooperatives to all members, facilitating members into the agribusiness chain, and improving the cluster of the production system. The strategies applied for East Java Cooperatives are prioritized on human resources, institutions and empowerment, facilities and infrastructure, and finance.
\end{abstract}

Keywords: agricultural cooperative, KUD, RAT, institutional strengthening

JEL Classification: Q12, Q13, R58

\section{INTRODUCTION}

Studies around the role of cooperatives have been carried out on various topics. Cooperatives are always connected with improving the performance of small farmers who have limited resources in rural areas. This emphasizes the importance of the institutional aspects of farmers. Thus, cooperatives are much approached through new institutional economics (NIE) theories such as property rights, agency and transaction cost economics. This approach focuses on the life cycle for cooperatives (formation, growth, reorganization) to always adapt to change economic environments characterized by

\footnotetext{
* Corresponding author email: triono.faperta@unej.ac.id, ISSN 2615-6075 online; ISSN 2615-6946 print @UWG Press, 2019

OJS http://publishing-widyagama.ac.id/ejournalv2/index.php/jsed/
}

technological change (Ortmann \& King, 2007),

Cooperatives need to recognize the framework of modern organizations, to develop cooperation in utilizing the potential economic of the region. Cooperation will integrate economic chains, link various forms of organization, form an agroindustrial integration together with minimizing production risks and eventually for sustainable viability (Koguashvili, 2016). Cooperatives collaborate with other business actors, allocate agricultural input resources, and reap capital formation to drive the regional economy (Buccola, 2014).

Cooperatives as one of the business ventures in Indonesia's economic development need to be developed systematically and continuously to support economic strengthening and prosperity. Efforts around to develop cooperatives have been carried out through policies and programs in 
various fields. The policies of cooperatives in Indonesia receive institutional support and technical assistance in the framework of strengthening the small and medium enterprise economy (Susilo, 2013). One of the efforts to improve the role of cooperatives is to strengthen competitiveness, so their products can be accepted by the community. Cooperatives should show their competitiveness dealing with changes in the strategic environment or government policies. Now, the abundant government budget is sent to villages through various programs. Cooperatives should be able to take advantages of these opportunities (Murwadji, Rahardjo, \& Hasna, 2017)

Agricultural cooperatives are one type of cooperatives engaged in agriculture or operating in the rural area. Agricultural cooperatives are always associated with Koperasi Unit Desa (KUD)/ Village Unit Cooperative. KUD generally conducts business relating to certain agricultural commodities or supporting activities. The activities at the KUD include the provision of seeds, pesticides, agricultural tools and machinery; processing of agricultural products, product marketing or processing (Buccola, 2014). Some agricultural cooperatives also provide capital and develop certain skills to strengthen management or technical aspects.

However, at the operational level, KUD managing its business is often limited to activities with low productivity, even works in subsistence agriculture that uses low cultivation technology. Cooperative business activities are also often faced by conflicts of interest. When the business begins to be profitable, especially in the downstream agribusiness subsystem (such as processing and trading), the businesses are often easily intervened by other business actors or government. This is also stated by Ortmann \& King (2007) that cooperative always faces the situation of free-rider, control and cost problems caused by vaguely defined property rights. As a result, the position and works of KUD continue to be not optimal, resulting in low economic business value. Farmers as members and main economic players of cooperatives receive low welfare and live in poverty (Widjajani, et al, 2014).

East Java is the province that has the most role in fostering performance of cooperatives. In East
Java, KUD is able to become a driving force for supporting a successful rural economy. Meanwhile, KUD in other provinces generally does not optimally operate and are in an inactive condition. The number of KUD registered in this province are 702 units. There are around $40 \%$ or 280 KUD that still actively operate, while the rest are in a stagnant condition.

The performance of KUD is supported by Pusat Koperasi Unit Desa (Puskud)/ the Center of Village Cooperative. Puskud in East Java conducts guidance for KUD to strengthen its business efforts with various programs. Puskud conducts breakthrough activities, including building business synergy with KUD through the supply of savings and loan units and integrated Payment Point Online Bank (PPOB) services. For hard work and synergy among managers, several KUD are active again and healthy operated. It means that the number of KUD that are active again reach 680 units or around $96 \%$ of KUD. However, there are still around 22 or $4 \%$ of KUD that are not yet active and operate normally.

KUD's performance in East Java is still potential to be developed even though the challenges in coming years also increase. These challenges need to be answered by identifying a variety of potential resources in the KUD business venture. From the above conditions, this research aims to explore strategic issues around KUD activities, measure financial resource efficiency, find models for strengthening agricultural cooperative businesses, and develop recommendations for strengthening the business of agricultural cooperatives in East Java.

\section{RESEARCH METHOD}

The research approach used was qualitative and quantitative descriptive. The research location was determined purposively. Those were in Malang, Lumajang, Bojonegoro, Tulungagung, Madiun, Situbondo, Banyuwangi, and Sumenep. Data collected were secondary and primary data. Secondary data were obtained from the provincial cooperative office, Puskud, and KUD. Primary data were obtained from interviews with key informants and cooperative managers. Data variables included KUD population characteristics, KUD financial 
performance, and SWOT. The data were analyzed by using a descriptive approach. It was done by calculating financial ratios and SWOT analysis. The SWOT analysis (F. Rangkuti, 2006) was directed at measuring the strengthening of cooperative businesses. The Force Field Analysis (FFA) (Murdock, 2018) method was applied to design agricultural cooperative business models and institutional strengthening of cooperatives in East Java.

\section{RESULT AND DISCUSSION}

\section{Performance and Issues}

The problems faced by most cooperatives are the inadequate quality of resources and the late of management to follow developments. The low in the cooperative performance is due to a lack of ability to link cooperation network and to utilize technology, the weak marketing, and the low of human resource competency.

The low quality of institutions and management of cooperative organizations will cause cooperative performance to be not optimal (Table 1). In cooperative business ventures, it takes several business activities that lead to dependence between the business activities and its members (P. A. Rangkuti, 2010). Dependence is perceived to have never been achieved because cooperative members are disappointed by the weak management and low quality of service. The low performance of cooperatives is also a result of poor cooperative capacity and resources to manage productive resources related to capital, information, technology, markets, and other production factors.

Table 1. Activity and Performance of Cooperatives in East Java

\begin{tabular}{|c|c|c|c|c|c|c|}
\hline Indicators & Unit & 2011 & 2012 & 2013 & 2014 & 2015 \\
\hline Number of members & thousand persons & 7021 & 7216 & 7249 & 7522 & 7622 \\
\hline Number of active cooperatives & units & 25149 & 25449 & 27031 & 27156 & 27461 \\
\hline Number of inactive cooperatives & units & 3996 & 3710 & 3710 & 3710 & 3710 \\
\hline Number of cooperatives held RAT & units & 14089 & 15306 & 16924 & 22788 & 11288 \\
\hline Business Volume & Billion Rp & 26.29 & 28.52 & 28.83 & 34.89 & 113.98 \\
\hline Managers & Person & 6070 & 6664 & 6835 & 6903 & 7846 \\
\hline Employees & Person & 69360 & 70950 & 71299 & 148410 & 149047 \\
\hline
\end{tabular}

Source: Cooperative Performance Report in the fourth quarter in 2015

The other problems faced by cooperatives are business development, uncertainty, and unclear licensing procedures. This results in increased transaction costs, business processes and unfair competition, and lack of coordination among institutions in empowering cooperatives. In addition, problems often found include technology, management, information, and markets. Consequently, cooperative operations tend to be high-cost. The regulations imposed on cooperatives often place cooperatives in inefficiency, or only for the sake of meeting local government revenue budget targets.

The disadvantageous cooperative position makes them more difficult to move forward. Government agencies and private companies will limit themselves to cooperate with cooperatives. Therefore, cooperative activities and services to its members are also very limited, resulting in a lack of distribution of production and cooperative services to its members. It is important to note that the limited access to productive resources dealing with increased capacity is also faced by cooperatives. Limited access is a lack of collateral, the availability of cooperatives to get loans/financial capital from banks or other financial institutions.

\section{The Resources of Cooperatives}

\section{a. Malang Regency}

Cooperative resources in Malang Regency are presented by using financial ratio data that is available from the Tumpang Sari Pandito cooperative. Based on the analysis of Internal Factor Analysis Summary (IFAS), the strength factor has the highest score on 'The existence of manager motivation in developing cooperative' with 
a score of 0.32 . For weakness factor, the highest score is on 'The limited conception about cooperative' with a score of 0.32. Meanwhile, based on the External Factor Analysis Summary (EFAS), the opportunity has the highest score on 'The existence of Annual Members Meeting (RAT) report' with a score of 0.32 . For threat factor, the highest score is presented on 'The dependence of cooperative activity to government' with the score of 0.28 .

Given the result, the strategy alternative on how the management should be focused on cooperative development implementation is based on a plan in Rapat Anggaran Tahunan (RAT)/ Annual Members Meeting so that all components stay in high motivation. The impact is that the cooperative becomes an institution that can facilitate its members to maximize all available potential resources.

The financial performance exhibited by Padita Over shows the relatively good condition based on the analysis of liquidity, solvency, profitability, and business activities (Table 2).

Table 2. Financial Ratio of Padita Tumpang Cooperative in Malang Regency

\begin{tabular}{|c|c|c|c|c|c|}
\hline Year & Ratio & (Real/Stan & $\begin{array}{l}e \\
\times 4 \\
\end{array}$ & & Conclusion \\
\hline \multirow{4}{*}{2014} & Liquidity & $(1075.8 / 125) \times 30$ & $=$ & 258.19 & \multirow{4}{*}{ Healthy } \\
\hline & Solvability & $(0.89 / 110) \times 30$ & $=$ & 0.24 & \\
\hline & Profitability & $(0.10 / 10) \times 40$ & $=$ & 0.40 & \\
\hline & Total & & $=$ & 258.83 & \\
\hline \multirow{4}{*}{2015} & Liquidity & $(1075.8 / 125) \times 30$ & $=$ & 258.19 & \multirow{4}{*}{ Healthy } \\
\hline & Solvability & $(0.90 / 110) \times 30$ & $=$ & 0.24 & \\
\hline & Profitability & $(0.11 / 10) \times 40$ & $=$ & 0.44 & \\
\hline & Total & & $=$ & 258.87 & \\
\hline
\end{tabular}

The ratio of $75 \%$ considered as a healthy financial cooperative.

Source: Balance Sheet Report of Cooperative Padita Tumpang 2014-2015 (Processed)

Table 3. Financial Ratio of Sri Tanjung Cooperative in Lumajang Regency

\begin{tabular}{|c|c|c|c|c|c|}
\hline Year & Ratio & (Real/Stano & $\begin{array}{l}e \\
x h \\
\end{array}$ & & Conclusion \\
\hline \multirow{4}{*}{2014} & Liquidity & $(110.07 / 125) \times 30$ & $=$ & 26.41 & \multirow{4}{*}{ Unhealthy } \\
\hline & Solvability & $(66.78 / 110) \times 30$ & $=$ & 18.21 & \\
\hline & Profitability & $(0.03 / 10) \times 40$ & $=$ & 0.11 & \\
\hline & Total & & $=$ & 44.73 & \\
\hline \multirow{4}{*}{2015} & Liquidity & $(113.08 / 125) \times 30$ & $=$ & 27.14 & \multirow{4}{*}{ Unhealthy } \\
\hline & Solvability & $(29.38 / 110) \times 30$ & $=$ & 8.01 & \\
\hline & Profitability & $(0.01 / 10) \times 40$ & $=$ & 0.03 & \\
\hline & Total & & $=$ & 35.18 & \\
\hline
\end{tabular}

The ratio of $75 \%$ considered as a healthy financial cooperative.

Source: Balance Sheet Report of Cooperative Sri Tanjung 2014-2015 (Processed)

Table 2 shows that the weight score was $258.83 \%$ in 2014 and $258.87 \%$ in 2015 . It indicated that Tumpang Sari Pandito Cooperative was considered an independent cooperative. In other words, the cooperative has reached the prescribed standards, so it is not urgent to have assistance from the government office for cooperative and small business training. However, cooperatives still need supervision to maintain the financial performance of the cooperative to make it always healthy.

\section{b. Lumajang Regency}

Cooperative resources in Lumajang Regency are measured by using financial ratio that the data are available from Sri Tanjung cooperative. The strength factor using IFAS analysis displays the highest score in 'Cooperative regularly holds RAT' with the score of 0.32 . For Weakness factor, it has the highest score on 'Business partnership has not developed yet' with the score of 0.18. Meanwhile, based on EFAS, the opportunity factor has the highest score in 'Increasing and various members 
need' with the score of 0.32 . For challenge/threat factor, the highest score is in 'Competition with

The strategy alternative of the cooperative is focused on developing collectivity so that all members ensure their roles and deliver innovation in RAT. The impact is expected to enable an increase activity performance of members in the cooperative. The financial performance exhibited by Padita Over shows the relatively good condition based on the analysis of liquidity, solvency, profitability, and business activities (Table 3 ).

Table 3 shows that the weight score was $44.73 \%$ in 2014 and $35.18 \%$ in 2015. It indicated that Sri Tanjung Cooperative was considered an unhealthy cooperative. The cooperative has not reached the prescribed standards, so it immediately needs assistance from the government office for cooperative and small business training. The cooperative also need much supervision to improve financial performance.

\section{c. Banyuwangi Regency}

Cooperative resources in Banyuwangi Regency are measured by using financial ratio that the data other business entity' with the score of 0.28 .

are available from the Jaya Makmur cooperative. Based on IFAS analysis, the strength factor presents the highest score in 'Business service that is still related to agriculture' with the score of 0.32 . For Weakness factor, it has the highest score of 0.32 on 'Business partnership has not developed yet'. Meanwhile, EFAS for Opportunity factor has the highest score of 0.32 in 'the increase in food demand'. For challenge/threat factor, the highest score is in 'Consumer demand to food quality' with the score of 0.32 .

The alternative strategy of the cooperative is focused on building an economic partnership with private business that operates in the local level. This alternative confirms the study of Nafanu (2018) which explores the benefit of partnership with government, private sector or smallholders. The impact is expected that cooperative members will have more acces in the financial benefit that guarantees their prosperity.

Table 4. Financial Ratio of Jaya Makmur Cooperative in Banyuwangi Regency

\begin{tabular}{|c|c|c|c|c|c|}
\hline Year & Ratio & (Real/Stanc & $\begin{array}{l}e \\
x W\end{array}$ & & Conclusion \\
\hline \multirow{4}{*}{2014} & Liquidity & $(91.29 / 125) \times 30$ & $=$ & 21.9 & \multirow{4}{*}{ Unhealthy } \\
\hline & Solvability & $(79.41 / 110) \times 30$ & $=$ & 21.65 & \\
\hline & Profitability & $(1.69 / 10) \times 40$ & $=$ & 6.76 & \\
\hline & Total & & $=$ & 50.31 & \\
\hline \multirow{4}{*}{2015} & Liquidity & $(100.69 / 125) \times 30$ & $=$ & 24.14 & \multirow{4}{*}{ Unhealthy } \\
\hline & Solvability & $(69.55 / 110) \times 30$ & $=$ & 18.96 & \\
\hline & Profitability & $(1.06 / 10) \times 40$ & $=$ & 4.24 & \\
\hline & Total & & $=$ & 47.34 & \\
\hline
\end{tabular}

The ratio of $75 \%$ considered as a healthy financial cooperative.

Source: Balance Sheet Report of Cooperative Jaya Makmur 2014-2015 (Processed)

Table 4 shows that the weight score was $50.31 \%$ in 2014 and $47.34 \%$ in 2015 . It indicated that Jaya Makmur Cooperative was considered an unhealthy cooperative. The cooperative performance is lower than the prescribed standards, so it immediately needs assistance from the government office for cooperative and small business training. The cooperative needs many coachings to improve financial performance as well.

d. Situbondo Regency
Cooperative resources are identified by using financial ratio that the data are available from the Serba Usaha Karya Tani cooperative. IFAS of strength factor has the highest score of 0.32 in 'The existence of manager motivation in developing cooperative'. For Weakness factor, it has the highest score of 0.32 on 'Not all members understand the Articles of Association'.

Meanwhile, EFAS for Opportunity factor has the highest score of 0.28 in 'the growth of the formal financial institution'. For challenge/threat factor, 
the highest score is in 'Society has not been used to be in formal organization' with the score of 0.32 .

Given the result, the strategy alternative is focused on strengthening cooperation with a formal financial institution for raising capital formation. The impact of the strategy is directed to grow the business capacity that is supported by adequate capital.
Table 5 shows that a weight score was $103.33 \%$ in 2014 and $116.51 \%$ in 2015 . It indicated that Serba Usaha Karya Tani Cooperative was considered a healthy cooperative. The cooperative performance is more than the expected standards. The necessity assistance from the government office for cooperative and small business training is still needed to maintain financial performance.

Table 5. Financial Ratio of Karya Tani Cooperative in Situbondo Regency

\begin{tabular}{|c|c|c|c|c|c|}
\hline Year & Ratio & (Real/Stan & $\mathrm{e}$ & & Conclusion \\
\hline \multirow{4}{*}{2014} & Liquidity & $(215.55 / 125) \times 30$ & $=$ & 51.73 & \multirow{4}{*}{ Healthy } \\
\hline & Solvability & $(21.43 / 110) \times 30$ & $=$ & 5.84 & \\
\hline & Profitability & $(11.44 / 10) \times 40$ & $=$ & 45.76 & \\
\hline & Total & & $=$ & 103.33 & \\
\hline \multirow{4}{*}{2015} & Liquidity & $(252.76 / 125) \times 30$ & $=$ & 60.66 & \multirow{4}{*}{ Healthy } \\
\hline & Solvability & $(22.03 / 110) \times 30$ & $=$ & 6.01 & \\
\hline & Profitability & $(12.46 / 10) \times 40$ & $=$ & 49.84 & \\
\hline & Total & & $=$ & 116.51 & \\
\hline
\end{tabular}

The ratio of $75 \%$ considered as a healthy financial cooperative.

Source: Balance Sheet Report of Cooperative Karya Tani 2014-2015 (Processed)

Table 6. Financial Ratio of Mekar Cooperative in Sumenep Regency

\begin{tabular}{|c|c|c|c|c|c|}
\hline Year & Ratio & (Real/Stanc & e & & Conclusion \\
\hline \multirow{4}{*}{2014} & Liquidity & $(115.57 / 125) \times 30$ & $=$ & 27.74 & \multirow{4}{*}{ Unhealthy } \\
\hline & Solvability & $(1.86 / 110) \times 30$ & $=$ & 0.51 & \\
\hline & Profitability & $(10.3 / 10) \times 40$ & $=$ & 41.2 & \\
\hline & Total & & $=$ & 69.45 & \\
\hline \multirow{4}{*}{2015} & Liquidity & $(110.06 / 125) \times 30$ & $=$ & 26.41 & \multirow{4}{*}{ Unhealthy } \\
\hline & Solvability & $(2.46 / 110) \times 30$ & $=$ & 0.67 & \\
\hline & Profitability & $(11.4 / 10) \times 40$ & $=$ & 45.6 & \\
\hline & Total & & $=$ & 72.68 & \\
\hline
\end{tabular}

The ratio of $75 \%$ considered as a healthy financial cooperative.

Source: Balance Sheet Report of Cooperative Mekar 2014-2015 (Processed)

\section{e. Sumenep Regency}

Cooperative resources are measured by using financial ratio that the data are available from the Mekar cooperative. IFAS of the Strength factor has the highest score of 0.32 in 'The existence of manager motivation in developing cooperative'. For Weakness factor, it has the highest score on 'Limited service because of limited facilities and infrastructure' with the score of 0.32 .

The EFAS of Opportunity factor has the highest score in the availability of information resource related to cooperatives' with the score of 0.32 . For challenge/threat factor, the highest score of 0.28 is in 'Society hasn't been used to be in the formal organization'.
Given the result, the strategy alternative should be focused on socializing and implementing cooperative values to all members. Furthermore, KUD would obtain many advantages of the available information optimally (P. A. Rangkuti, 2010). The impact is expected to strengthen economic interest and member's commitment to joining the cooperative organization.

Table 6 shows that a weight score was $69.45 \%$ in 2014 and $72.68 \%$ in 2015. It indicated that Mekar Cooperative was considered an unhealthy cooperative. The cooperative performance is lower than the prescribed standards, so it immediately needs assistance from the government office for cooperative and small business training. The 
cooperatives need supervision to improve financial performance.

\section{f. Tulungagung Regency}

Cooperative resources are identified by using financial ratio that the data are available from the Gapoktan Harapan Makmur Cooperative. Based on IFAS, the strength factor has the highest score in
'Cooperative regularly holds RAT' with the score of 0.32 . In weakness factor, the highest score is 0.21 on 'Manager's limited entrepreneurial spirit'. Meanwhile, EFAS of Opportunity factor has the highest score in 'Increasing food demand' with the score of 0.32 . For challenge/threat factor, the highest score is 0.28 in 'Risky agricultural business'.

Table 7. Financial Ratio of Gapoktan Harapan Makmur in Tulungagung Regency

\begin{tabular}{|c|c|c|c|c|c|}
\hline Year & Ratio & $\begin{array}{r}\mathrm{S} \\
\text { (Real/Standa }\end{array}$ & $\begin{array}{l}e \\
x w\end{array}$ & & Conclusion \\
\hline \multirow{4}{*}{2014} & Liquidity & $(1362.91 / 125) \times 30$ & $=$ & 327.09 & \multirow{4}{*}{ Healthy } \\
\hline & Solvability & $(5.51 / 110) \times 30$ & $=$ & 1.5 & \\
\hline & Profitability & $(1.41 / 10) \times 40$ & $=$ & 5.64 & \\
\hline & Total & & $=$ & 334.23 & \\
\hline \multirow{4}{*}{2015} & Liquidity & $(951.6 / 125) \times 30$ & $=$ & 228.38 & \multirow{4}{*}{ Healthy } \\
\hline & Solvability & $(7.91 / 110) \times 30$ & $=$ & 2.15 & \\
\hline & Profitability & $(1.02 / 10) \times 40$ & $=$ & 4.08 & \\
\hline & Total & & $=$ & 234.61 & \\
\hline
\end{tabular}

The ratio of $75 \%$ considered as a healthy financial cooperative.

Source: Balance Sheet Report of Gapoktan Harapan Makmur 2014-2015 (Processed)

Table 8. Financial Ratio of Sri Mulyo Cooperative in Madiun Regency

\begin{tabular}{|c|c|c|c|c|c|}
\hline Year & Ratio & (Real/Standar & $\mathrm{e}$ & & Conclusion \\
\hline \multirow{4}{*}{2014} & Liquidity & $(169.82 / 125) \times 30$ & $=$ & 40.75 & \multirow{4}{*}{ Healthy } \\
\hline & Solvability & $(42.37 / 110) \times 30$ & $=$ & 11.55 & \\
\hline & Profitability & $(10.26 / 10) \times 40$ & $=$ & 41.04 & \\
\hline & Total & & $=$ & 93.34 & \\
\hline \multirow{4}{*}{2015} & Liquidity & $(160.54 / 125) \times 30$ & $=$ & 38.52 & \multirow{4}{*}{ Healthy } \\
\hline & Solvability & $(44.44 / 110) \times 30$ & $=$ & 12.12 & \\
\hline & Profitability & $(11.02 / 10) \times 40$ & $=$ & 44.08 & \\
\hline & Total & & $=$ & 94.72 & \\
\hline
\end{tabular}

The ratio of $75 \%$ considered as a healthy financial cooperative.

Source: Balance Sheet Report of Cooperative Sri Mulyo 2014-2015 (Processed)

The alternative strategy is focused on linkage and economic cooperation with Badan Urusan Logistik (BULOG). The impact is directed to strengthen an economic institution of cooperative for supporting the increase of food production as well as providing welfare for its members.

Table 7 shows that a weight score was $334.23 \%$ in 2014 and $234.61 \%$ in 2015 . It indicated that Gapoktan Harapan Makmur Cooperative was considered an independent cooperative. The cooperative performance is more than the expected standards. The necessity assistance from the government office for cooperative and small business training is still needed to maintain healthy financial performance.

\section{g. Madiun Regency}

Cooperative resources are measured by using financial ratio data available from the Sri Mulyo Cooperative. IFAS of Strength factor has the highest score of 0.32 in 'Business service that is still related to agriculture'. For Weakness factor, it has the highest score on 'Limited access of farmer to resources' with the score of 0.28 . Meanwhile, EFAS of Opportunity factor has the highest score in 'The existence of RAT report' factor with the score of 0.32 . For challenge/threat factor, the highest score is in 'Society traumatic to the existence of cooperative' with the score of 0.32 .

The strategy alternative should be focused on facilitating its members to maximize their potential in the agribusiness supply chain. The impact is expected that members joining cooperative will be 
more creative and increase cooperative performance. The result of the counting of the financial ratio of KUD Sri Mulyo meet the prescribed standard. The necessity of assistance from the government office for cooperative and small business training is still needed to maintain healthy financial performance (Table 8).

Table 8 shows that a weight score was $93.34 \%$ in 2014 and $94.72 \%$ in 2015 , so that it can be concluded that KUD Sri Mulyo in 2014 and 2015 was considered as independent cooperative because it has reached the determined standard so that it does not need coaching from Departemen Koperasi dan Pembinaan Pengusaha Kecil.

\section{h. Bojonegoro Regency}

Cooperative resources are measured by using financial ratio data that are available from Karya Tirta Cooperative. IFAS of Strength factor has the highest score in 'The existence of the manager's motivation in developing cooperative' with the score of 0.24 . For Weakness factor, the highest score is 0.18 representing 'Business in savings and loan hasn't been optimized in providing food'.

Moreover, EFAS of Opportunity factor has the highest score in 'Members' need are increasing and various' with the score of 0.24 . For challenge/threat factor, the highest score is 0.24 with the statement of 'Risky agricultural business'.

Table 9. Financial Ratio of Karya Tirta Cooperative in Bojonegoro Regency

\begin{tabular}{|c|c|c|c|c|c|}
\hline Year & Ratio & (Real/Sta & $\begin{array}{l}e \\
x W\end{array}$ & & Conclusion \\
\hline \multirow{4}{*}{2014} & Liquidity & $(1679.2 / 125) \times 30$ & $=$ & 403.01 & \multirow{4}{*}{ Healthy } \\
\hline & Solvability & $(0.05 / 110) \times 30$ & $=$ & 0.01 & \\
\hline & Profitability & $(0.15 / 10) \times 40$ & $=$ & 0.6 & \\
\hline & Total & & $=$ & 403.62 & \\
\hline \multirow{4}{*}{2015} & Liquidity & $(1489.3 / 125) \times 30$ & $=$ & 357.43 & \multirow{4}{*}{ Healthy } \\
\hline & Solvability & $(0.06 / 110) \times 30$ & $=$ & 0.01 & \\
\hline & Profitability & $(0.14 / 10) \times 40$ & $=$ & 0.56 & \\
\hline & Total & & $=$ & 358.00 & \\
\hline
\end{tabular}

The ratio of $75 \%$ considered as a healthy financial cooperative.

Source: Balance Sheet Report of Cooperative Karya Tirta 2014-2015 (Processed)

The strategy alternative should be focused on improving the different type of business through clustering process supported by the cooperation of various stakeholders. The impact is expected to meet the real needs of all members.

Table 9 shows that a weight score was $403.62 \%$ in 2014 and $358.00 \%$ in 2015 . It indicated that KUD Sri Mulyo was considered as an independent cooperative. The cooperative performance exceeds the expected standards. The necessity of assistance from the government office for cooperative and small business training is still needed to improve healthy financial performance.

\section{Strengthening the Institution and Supporting Food Sovereignty}

The FFA analysis produces a number or score regarding driving factors and inhibiting factors, which are expressed as Totally Weight Values (TNB). In the case where the highest TNB score is found, it is considered as succeed key factor. This factor is also important for developing Agriculture Cooperative Institutions in Supporting Food Sovereignty in East Java.

FKK is divided into two groups, namely driving and inhibiting factors. The driving factor is the factor in which the cooperative becomes an institution that has a close relationship with the government both central and regional. It has a score of 1.04. This means that cooperatives become a strong economic institution and are able to play a role in coordinating business development and developing activities for lower economic groups. The role of cooperatives is very relevant to economic dynamics of small and medium enterprises that spread in the grassroots (Susilo, 2013).

The inhibiting factor is a factor in which business partnerships between agricultural cooperatives and other business actors have been well implemented. This inhibiting factor shows a relatively low score, which is 0.81 . This means that 
the management of cooperatives has not been able to link well with financial institutions and other business actors. The internal problems of cooperative management appear to be still dominant and have not been able to see incentives from government support.

The strategy arrangement is carried out by adjusting between the direction of optimization driving factors and the direction of improvement inhibiting factors. This means that there are alternative combination of key drives and key inhibits as the basis for strategy formulation. Therefore, the pattern of agribusiness partnerships for instance among farmers, companies, cooperatives and collectors, should be done in various ways to adjust the character and context of the environment (Purnaningsih, 2017).
Strategy development is directed towards strengthening Cooperative and Businesses Institutions to Support Food Sovereignty in East Java. The strategy is expected to be able to build a model for developing agricultural cooperatives, which is ready to give a role to drive economic development and achieve community welfare. Ito, Bao, \& Su (2012) also confirm that the agricultural cooperative is an important way for farmers to improve their economic condition.

The following is the Agricultural Cooperative Institutional Model and Business Strengthening in Supporting Food Sovereignty in East Java (Figure 1). Given the model, the need to strengthen cooperation and business agricultural institutions in supporting food sovereignty is presented below:

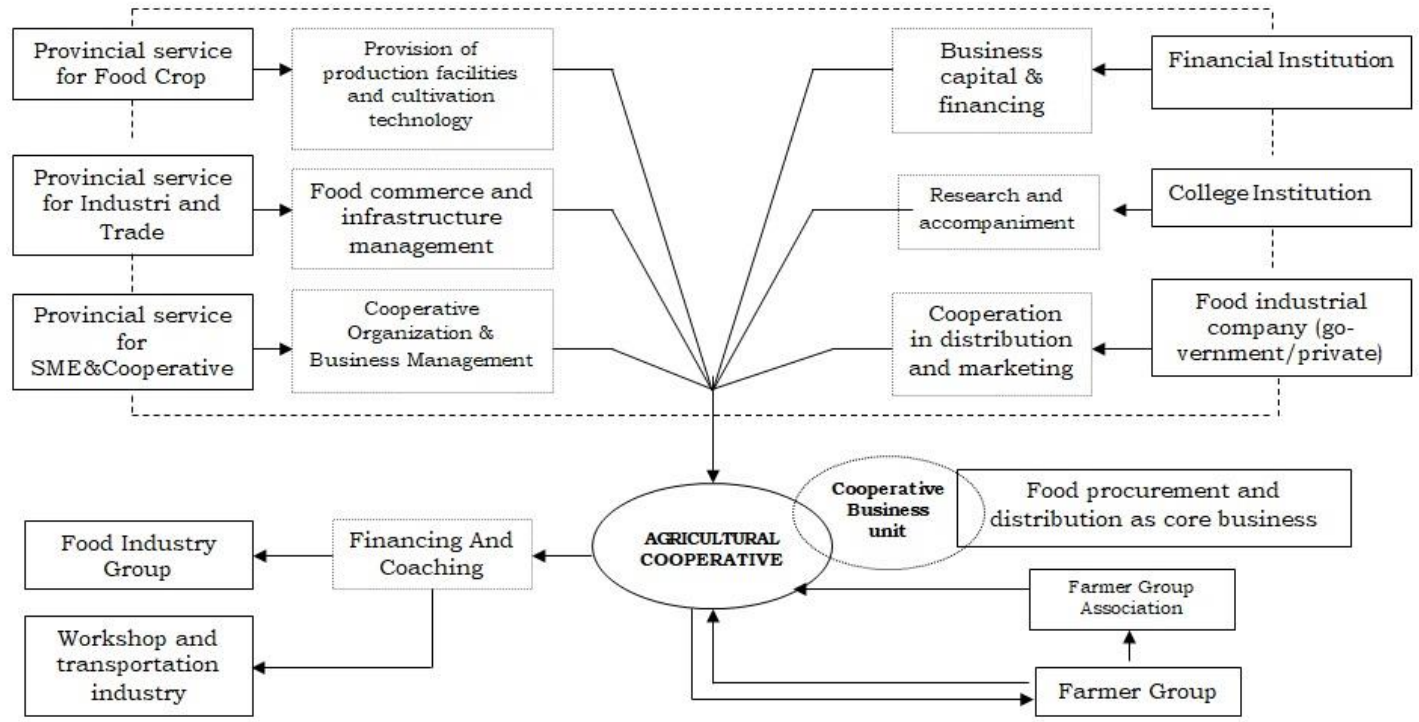

Figure 1. Model Design of Agricultural Cooperative Institution and It's Business Strengthening in East Java

\section{Human Resource Policy}

Human resources that work in the management organization of cooperatives should have taken a part in Training and Education concerning Cooperative and Entrepreneurship. Human resources from government institutions should have several main qualifications. Those are understanding cooperative problems both theoretically and practically; being able to communicate effectively based on the local, social and cultural community; having adequate facilities support; and attending regular education and training to meet the needs and interests of dynamic cooperatives. Human resources from the government function such as a consultant, mentor, and executive including monitoring and evaluation in agricultural cooperation for supporting food sovereignty. 


\section{Institutional and Empowering Policy}

The performance of agricultural cooperatives to support food sovereignty should be mapped and focused on potential resources. It also should build economic cooperation oriented to financial benefits and improve the welfare of members. The forms of mapping include (a) cooperatives focusing on inputs (raw materials) and warehousing; (b) cooperatives focusing on agro- or processing industry; and (c) cooperatives focusing on marketing activities.

The government as a facilitator and mediator gives freedom to the private sector or companies to build economic partnerships with agricultural cooperatives based on food sovereignty. The partnership will work effectively and productively if partners are able to take their position as catalysts without intervention in decision making. The existence of agriculture-based food sovereignty not only produces financial benefits but also strengthens the role of cooperative institutions to fulfill the needs of its members. Mentoring and consultation by the government to support agricultural-based food sovereignty use an egalitarian humanistic approach. The important thing to do is the interaction of mutual learning, mutual respect, and appropriate decision making.

\section{Facility and Infrastructure Policy}

The provision of facilities and infrastructure to support the development of agricultural-based food sovereignty should be based on the needs or interests of business unit development. This will also operate well by financial assistance support based on the financial capability of the cooperative (Ito et al., 2012). Government policies at the local level in terms of transportation and telecommunications are immediately provided because this is often a problem in rural areas (Purnaningsih, 2017)

\section{Financing Policy}

The government encourages formal financial institutions to collaborate with cooperatives that support the implementation of food sovereignty. Strengthening capital through special programs can be provided by the government through public accountability. The government facilitates the need for cooperatives to have management information system technology based on the food sovereignty. The information system can be accessed openly by members, the government or other stakeholders, as administrative services and moral responsibility to the public.

\section{CONCLUSION AND SUGGESTION}

The agricultural cooperatives performance in East Java still has various problems, including management, technology, marketing of agricultural products, human resources, and financing. The strategic issue of cooperative development in East Java is to build cooperation with various parties to increase economic value added, to improve farmer's term of trade, to open access to food distribution, to increase the quality and quantity of agricultural products, to improve management quality, and to strengthen financially.

The number of active cooperatives in 2015 was 27461 units with 7.62 million members. The number of cooperatives that hold Annual Member Meetings is 11288 cooperatives, with a business volume of Rp. 113.98 billion and a business surplus of Rp. 98.64 billion. The number of managers and employees of cooperatives is 7846 managers and 149 thousand employees, respectively. Agricultural cooperatives show a strong institutional position to support food sovereignty.

Good performance of cooperative was presented by the Padita Tumpang Farmers Cooperative in Malang Regency, Karya Tirta LKM-A Cooperative in Situbondo District, Harapan Makmur Cooperative in Tulungagung and Sri Mulyo Districts in Madiun Regency.

The cooperative development strategy is focused on implementing RATs, developing innovation, making economic partnerships, strengthening capital formation, applying positive values of cooperatives to all members, facilitating members into the agribusiness chain, and improving the cluster of the production system.

The agricultural cooperative institution and business strengthening in East Java are models of institutional partners in driving business ventures to achieve social welfare. The agricultural cooperative institutional and business strengthening policy strategy in East Java is focused on human 
resources, institutions and empowerment, facilities and infrastructure, and financing.

Cooperatives should be able to facilitate the needs of their members and maximize potential resources. Rapat Anggaran Tahunan (RAT)/ Annual Member Meetings should get approval and attendance by representatives of government officials involved. The activities to build members' confidence are held by developing partnerships with various stakeholders.

\section{REFERENCES}

Buccola, S. T. (2014). Agricultural Cooperatives. In Encyclopedia of Agriculture and Food Systems (pp. 71-80). Elsevier. https://doi.org/10.1016/B978-0-444-525123.00125-X

Ito, J., Bao, Z., \& Su, Q. (2012). Distributional effects of agricultural cooperatives in China: Exclusion of smallholders and potential gains on participation. Food Policy, 37(6), 700-709. https://doi.org/10.1016/j.foodpol.2012.07.009

Murdock, D. H. (2018). Force Field Analysis. In Auditor Essentials (pp. 247-250). Auerbach Publications. https://doi.org/10.1201/9781315178141-54

Murwadji, T., Rahardjo, D. S., \& Hasna. (2017). Koperasi Versus BUMDes dalam Peningkatan Kesejahteraan Masyarakat Desa. ACTA DIURNAL Jurnal Ilmu Hukum Kenotariatan, $1(1)$ 1-8. $\quad$ Retrieved from http://jurnal.fh.unpad.ac.id/index.php/jad/articl e/view/63/73

Nafanu, S. (2018). Model Pengembangan Koperasi Unit Desa (KUD) Berbasis Agribisnis di Pedesaan Swapraja Biboki. AGRIMOR, 1(2), 30-31. https://doi.org/10.32938/ag.v1i02.103

Ortmann, G. F., \& King, R. P. (2007). Agricultural cooperatives I: History, theory and problems. Agrekon, 46(1), 18-46. https://doi.org/10.1080/03031853.2007.952376 $\underline{0}$

Purnaningsih, N. (2017). Strategi Kemitraan Agribisnis Berkelanjutan. Sodality: Jurnal Sosiologi Pedesaan, 1(3). https://doi.org/10.22500/sodality.v1i3.5899

Rangkuti, F. (2006). Analisis SWOT Teknik Membedah Kasus Bisnis. PT. Gramedia Pustaka Utama.

Jakarta. https://doi.org/10.3975/cagsb.2015.05.08

Rangkuti, P. A. (2010). Peran Komunikasi dalam Modernisasi Pertanian Berbasis Koperasi. Jurnal Komunikasi Pembangunan, 8(1), 42-48. Retrieved from http://journal.ipb.ac.id/index.php/jurnalkmp/arti cle/download/5694/4322

Susilo, E. (2013). Peran Koperasi Agribisnis dalam Ketahanan Pangan di Indonesia. Jurnal Dinamika Ekonomi Dan Bisnis, 10(1), 95-104 Retrieved from https://ejournal.unisnu.ac.id/JDEB/article/down oad/28/39 